\title{
The influence of spatial distribution of producer services on high quality development of manufacturing industry
}

\author{
LiXian Chen ${ }^{1 *}$, XinMing Cai ${ }^{1}$, and KaiZhang Zou ${ }^{1}$ \\ ${ }^{1}$ School of Economics and trade, Guangdong University of Foreign Studies, GuangZhou, China
}

\begin{abstract}
Based on the provincial data of China from 2004 to 2018, this paper empirically tests the impact of the spatial distribution of producer services on the high-quality development of manufacturing. It is found that the spatial distribution of producer services significantly promotes the high-quality development of manufacturing, and there is no heterogeneity of geographical location and economic development level.
\end{abstract}

\section{Introduction}

Manufacturing is the mainstay of the national economy. In order to promote the transformation from "made in China" to "created in China" and from a major manufacturer to a strong manufacturer, the key is to promote high-quality development of the manufacturing industry. Studies have shown that producer services are important intermediate inputs of manufacturing industry, which will affect the high-quality development of manufacturing industry. The theory of new economic geography endows the coordinated spatial development relationship between manufacturing industry and producer services, and the two present a "new industrial space" model of spatial externality and spatial division of labor (Zhang and Han, 2019). If producer services can overcome the traditional spatio-temporal inseparability and storage of production and consumption, that is, producer services can realize spatial correlation among regions, which will promote the high-quality development of manufacturing industry. Therefore, how the spatial correlation of producer services influences the high-quality development of manufacturing industry will be the focus of this paper.

\section{Variables and Data}

\subsection{Variables}

\subsubsection{Spatial distribution of producer services}

With the development of information technology, the universality of the Internet, the acceleration of global division of labor and the emergence of service outsourcing, the spatial distribution of producer services has broken through the administrative boundaries and been affected by the development of producer services in neighboring regions. In reality, the producer services needed for the economic development of a region not only come from the spillover effect of the region but also from the neighboring (more developed) regions. Therefore, in order to accurately measure the spatial distribution of producer services, this paper constructs the structure based on the weight of provinces spatial distance and the number of producer services employees. Among them, the weight of provinces spatial distance is calculated based on the longitude and latitude data of each province, and the data source is the Gaode map. Where, Equation (1) refers to the weight of provinces space distance, meaning that the greater the distance between provinces, the smaller the weight.

$$
\begin{aligned}
& \text { weight }_{i j}=\frac{\frac{\text { max_disatan } c e-d i s a \tan c e_{i j}}{\max \_d i s \tan c e}}{\sum_{i=1}^{k} \frac{\text { max_disatance-disa } \tan c e_{i j}}{\max \_ \text {dis } \tan c e}} \\
& \left(\begin{array}{c}
\text { service }_{1 t} \\
\text { service }_{2 t} \\
\ldots \\
\text { service }_{k t}
\end{array}\right)=\left(\begin{array}{cccc}
\text { weight }_{11} & \text { weight }_{12} & \ldots & \text { weight }_{1 k} \\
\text { weight }_{21} & \text { weight }_{22} & \ldots & \text { weight }_{2 k} \\
\ldots & \ldots & \ldots & \ldots \\
\text { weight }_{k 1} & \text { weight }_{k 2} & \ldots & \text { weight }_{k k}
\end{array}\right)\left(\begin{array}{c}
\text { labor }_{1 t} \\
\text { labor }_{2 t} \\
\ldots \\
\text { labor }_{k t}
\end{array}\right)
\end{aligned}
$$

\subsubsection{High-quality development of manufacturing industry}

High-quality development of manufacturing industry is under the guidance of new development concepts, technological innovation is the core driving force, and high-end manufacturing, intelligent manufacturing, high-quality manufacturing and green manufacturing are the main starting points. This paper refers to the research of Jiang et al. (2019), to establish an evaluation index system for high-quality development of the manufacturing industry, and the details are shown in Table 1.

\footnotetext{
*Corresponding author: chenlixian2015@163.com
} 
Table 1 Evaluation index system for high quality development of manufacturing industry

\begin{tabular}{|l|l|l|}
\hline Index name & Index meaning & Indicator measurement method \\
\hline $\begin{array}{l}\text { economic } \\
\text { effectiveness }\end{array}$ & profit ratio of sales & total operating profit/revenue from main business \\
\hline $\begin{array}{l}\text { technological } \\
\text { innovation }\end{array}$ & $\begin{array}{l}\text { output level of technological } \\
\text { innovation }\end{array}$ & $\begin{array}{l}\text { number of effective invention patents/R\&D } \\
\text { expenditure }\end{array}$ \\
\hline green development & $\begin{array}{l}\text { energy consumption per unit of } \\
\text { industrial added value }\end{array}$ & total energy consumption/industrial added value \\
\hline brand Quality & product quality pass rate & $\begin{array}{l}\text { number of qualified products/finished products } \\
\text { produced by the manufacturing enterprise }\end{array}$ \\
\hline $\begin{array}{l}\text { integrative } \\
\text { development }\end{array}$ & internet penetration rate & $\begin{array}{l}\text { number of websites owned by manufacturing } \\
\text { enterprises/number of manufacturing enterprises }\end{array}$ \\
\hline
\end{tabular}

The specific steps are as follows: First, determine whether it is a positive indicator or a reverse indicator. Second, for the positive index, the formula is

$$
x_{i j}=\left(X_{i j}-X_{\min }\right) /\left(X_{\max }-X_{\min }\right)
$$

Thirdly, the formula for the reverse index is

$$
x_{i j}=\left(X_{\max }-X_{i j}\right) /\left(X_{\max }-X_{\min }\right)
$$

$x_{i j}$ is the measurement index value after standardization treatment; $X_{i j}$ is the original measurement index value. Fourthly, this paper uses the linear weighting method to get the overall index and sub-index of the high quality economic development of each province. The total exponent I is calculated by the formula

$$
I=\sum_{1}^{5} I_{j} w_{j}
$$

where, $I_{j}$ represents 5 indicators, and $w_{j}$ represents the weight corresponding to each indicator. Accurate weight assignment of each index is very important for total index calculation. In order to accurately characterize the weight of each index, this paper first calculates the information entropy of each measure index

$$
e_{j}=\ln (1 / 31) \sum_{i=1}^{31}\left(\left(x_{i j} / \sum_{i=1}^{31} x_{i j}\right) \ln \left(x_{i j} / \sum_{i=1}^{31} x_{i j}\right)\right)
$$

And further use information entropy to calculate the weight of each measure index

$$
w_{j}=\left(1-e_{j}\right) / \sum_{j=1}^{m}\left(1-e_{j}\right)
$$

\subsubsection{Control variables}

Based on the existing related studies, the following control variables are added in this paper. Government Intervention (GOV), this paper uses the ratio of local government fiscal expenditure to gross regional product to measure government intervention. Marketization degree (MAR), this paper uses the Wang Xiaolu et al. (2018) compiled the marketization index of China's sub-provinces to represent marketization. Since the index is only updated to 2016, 2016 data is also used for 2017 and 2018. Urbanization rate (URB), which is measured in this paper by the ratio of urban population to the total population of the region.

\subsection{Data}

The research samples in this paper are the panel data of 31 provinces in China from 2004 to 2018. The data in this paper are from the national and provincial statistical yearbooks and the website of the Bureau of Statistics.

\section{Research Method}

In order to analyze the impact of spatial distribution of producer services on high-quality development of manufacturing industry, this paper constructs the following econometric model:

$$
\mathrm{eco}_{i t}=\alpha+\beta \operatorname{serv}_{i t}+X_{i t} \lambda+\gamma_{t}+\varphi_{i}+\varepsilon_{i t}
$$

The subscript $\mathrm{t}$ represents the year, and the subscript $\mathrm{i}$ represents the province, eco indicates the high quality of economic development, serv represents the spatial distribution of producer services, $X^{\prime}$ represents a set of control variables, $\gamma_{t}$ and $\varphi_{i}$ represent year and province fixed effect respectively, $\varepsilon_{i t}$ represent the error term.

As the high quality development of manufacturing industry is a dynamic process of change, the development level of the previous period is bound to affect the current level. At the same time, let's think about endogeneity. Therefore, based on Equation (8), this paper introduces the lag period of the explained variable as the explanatory variable, and rewrote Equation (8) into the following dynamic panel model:

$$
\mathrm{eco}_{i t}=\alpha+\beta \operatorname{ser}_{i t}+\mu \mathrm{eco}_{i t-1}+X_{i t}^{\prime} \lambda+\gamma_{t}+\varphi_{i}+\varepsilon_{i t}
$$

$\mathrm{eco}_{i t-1}$ represents the high-quality economic development index of the last period, and the meaning of the other variables is the same as that of Equation (8).

\section{Empirical results and explanation}

\subsection{Baseline Regression}

Table 2 presents the estimation results from Equation (8). Column (1) reports the OLS regression results, after adding control variables and fixed effects, this paper finds that the spatial distribution of producer services significantly promotes the high-quality development of manufacturing. Specifically, when the spatial distribution 
of producer services increases by $1 \%$, the high-quality development level of manufacturing reaches 0.4092 . Column (2) - (4) respectively report the regression results of Fe, differential GMM and system GMM. This paper also finds that the estimated coefficient of spatial distribution of producer services is significantly positive. Besides, the high-quality development of the manufacturing industry in the previous period will significantly affect the high-quality development of the manufacturing industry in the current period. That is to say, the spatial distribution of producer services contributes to high-quality economic development and provides new sources, new drivers and new forces for high-quality manufacturing development.

Table 2 Baseline regression result

\begin{tabular}{|c|c|c|c|c|}
\hline & OLS & $\mathrm{FE}$ & differential GMM & system GMM \\
\hline serv & $\begin{array}{c}0.4092 * * * \\
(0.1273)\end{array}$ & $\begin{array}{c}0.3984 * * * \\
(0.1029)\end{array}$ & $\begin{array}{c}0.3789 * * * \\
(0.0924)\end{array}$ & $\begin{array}{c}0.4284 * * * \\
(0.1287)\end{array}$ \\
\hline L.eco & & & $\begin{array}{c}0.5827 * * * \\
(0.0929)\end{array}$ & $\begin{array}{c}0.5304 * * * \\
(0.0748)\end{array}$ \\
\hline control variable & yes & yes & yes & yes \\
\hline year fixed effect & yes & yes & yes & yes \\
\hline province fixed effect & yes & yes & yes & yes \\
\hline $\mathrm{R}^{2}$ & 0.4905 & 0.5022 & 0.4916 & 0.4782 \\
\hline $\operatorname{AR}(1)$ & & & $\begin{array}{l}-2.9301 \\
(0.0001)\end{array}$ & $\begin{array}{l}-3.3684 \\
(0.0001)\end{array}$ \\
\hline $\operatorname{AR}(2)$ & & & $\begin{array}{l}-1.9266 \\
(0.2008)\end{array}$ & $\begin{array}{c}1.0291 \\
(0.2324))\end{array}$ \\
\hline sargan test & & & $\begin{array}{l}58.9301 \\
(0.0000)\end{array}$ & $\begin{array}{l}73.0208 \\
(0.0000)\end{array}$ \\
\hline observations & 465 & 465 & 434 & 434 \\
\hline
\end{tabular}

In brackets is the standard error for clustering to an enterprise. ${ }^{* * *},{ }^{* *},{ }^{*}$ represent significance at 1,5 and 10 percent, respectively. The following tables are the same.

\subsection{Robustness Check}

In order to ensure the reliability of the above empirical results, this paper conducts robustness tests from the following three aspects. The concrete content and empirical results are as follows:

First, the index of high quality development of the explained variable in this paper is re-measured. Assume that all first-level indicators of high-quality development in manufacturing are essential to characterize and describe high-quality development in manufacturing, the index weight is re-calculated, the subjective weight method is adopted to set the weight of 0.2 for the five dimensional first-level indicators of the high quality development of the manufacturing industry. Second,
MAXDEA software was used to calculate the green total factor productivity of 31 provinces in China from 2009 to 2018, and it was used as the explained variable for regressions. Third, this paper draws on the research of Xuan and $\mathrm{Yu}$ (2017), regional altitude and urban road length are selected as instrumental variables of spatial distribution of producer services to reexamine the influence of spatial distribution of producer services on high-quality development of manufacturing industry. The estimated results are shown in Table 3 . In all cases, the influence of spatial distribution of producer services on high-quality development of manufacturing industry is significantly positive at the $1 \%$ level. This shows that the conclusion of this paper is very robust

Table 3 Robustness test results

\begin{tabular}{|l|c|c|c|}
\hline & $\begin{array}{c}\text { indicator weights are } \\
\text { re-measured }\end{array}$ & $\begin{array}{c}\text { green total factor } \\
\text { productivity }\end{array}$ & $\begin{array}{c}\text { instrumental variable } \\
\text { method }\end{array}$ \\
\hline serv & $\begin{array}{c}0.3891^{* * *} \\
(0.0783)\end{array}$ & $\begin{array}{c}0.1089^{* * *} \\
(0.0045)\end{array}$ & $\begin{array}{c}0.4781^{* * *} \\
(0.1821)\end{array}$ \\
\hline iv & & & yes \\
\hline control variable & yes & yes & yes \\
\hline year fixed effect & yes & yes & yes \\
\hline province fixed effect & yes & yes & $(0.0000)$ \\
\hline LM Statistics & & & 58.093 \\
& & & $(16.38)$ \\
\hline F Statistics & & & 0.5236 \\
\hline $\mathrm{R}^{2}$ & 0.4782 & 465 & 465 \\
\hline observations & 465 & & 465 \\
\hline
\end{tabular}

\subsection{Heterogeneity test}

Due to the highly unbalanced phenomenon of regional industrial structure adjustment and economic development in China, the influence of spatial distribution of producer services on high-quality 
development of manufacturing industry may also exist regional differences. Firstly, the samples are divided into eastern regions and central and western regions according to their geographical locations. Secondly, according to the regional economic development (per capita GDP), the provinces with average per capita GDP above are classified as developed regions, while the rest are classified as underdeveloped regions. The empirical results are shown in Table 4. It can be found that regardless of geographical location and economic development, the spatial distribution of producer services significantly promotes the high-quality development of manufacturing. This also shows that the research conclusion of this paper is very robust.

Table 4 Heterogeneity test results

\begin{tabular}{|c|c|c|c|c|}
\hline & \multicolumn{2}{|c|}{ geographic location } & \multicolumn{2}{|c|}{ economic development } \\
\hline & eastern region & $\begin{array}{l}\text { central and western } \\
\text { regions }\end{array}$ & developed regions & less-developed regions \\
\hline serv & $\begin{array}{c}0.3854 * * * \\
(0.0839)\end{array}$ & $\begin{array}{c}0.3105^{* * *} \\
(0.0271)\end{array}$ & $\begin{array}{c}0.4029 * * * \\
(0.1127)\end{array}$ & $\begin{array}{c}0.3893 * * * \\
(0.0926)\end{array}$ \\
\hline control variable & yes & yes & yes & yes \\
\hline year fixed effect & yes & yes & yes & yes \\
\hline province fixed effect & yes & yes & yes & yes \\
\hline $\mathrm{R}^{2}$ & 0.5738 & 0.5182 & 0.6039 & 0.5824 \\
\hline observations & 165 & 300 & 180 & 285 \\
\hline
\end{tabular}

\section{Conclusion and policy implications}

Based on China's provincial panel data from 2009 to 2018, this paper empirically examines the direction and extent of the impact of producer services' spatial distribution on the high-quality development of manufacturing. The empirical results show that: first, the spatial distribution of producer services significantly promotes the high-quality development of manufacturing industry. Secondly, the results of grouping also have significant promoting effect in terms of geographical location and economic development. Based on the above conclusions, this paper puts forward the following policy suggestions: accelerate the pace of service-oriented transformation of manufacturing industry, and strengthen the short board and weak areas in the construction of service industry.

\section{Acknowledgement}

Funding: This work was supported by National Natural Science Foundation of China (No.72003048), Ministry of education of Humanities and Social Science Project (No.20YJC790010), The 13th Five-Year Plan Project of
Philosophy and Social Science Development in Guangzhou, China (No. 2020GZQN30).

\section{References}

1. Zhang $\mathrm{Hu}$, Han Aihua. Whether the coupling of manufacturing and producer services can promote spatial coordination: A test based on data of 285 cities [J]. Statistical Research,2019,36(01):39-50.

2. Jiang Xiaoguo, He Jianbo, Fang Lei. easurement of high quality development level of manufacturing industry, regional differences and promotion paths $[\mathrm{J}]$. Shanghai Economic Research Journal, 2019(7): 70-78.

3. Wang Xiaolu, Fan Gang, Hu Lipeng. Marketization Index Report of China's Provinces (2018) [M]. Social Sciences Academic Press, 2018.

4. Xuan Ye, Yu Yongze. The Effect of Producer Services Agglomeration on Total Factor Productivity of Manufacturing Firms: Evidence from 230 Urban Micro-firms [J].Journal of Quantitative and Technical Economics,2017(2):89-104. 